\title{
The Effectiveness of Jigsaw Strategy in Geography Subject of Earth as Living Space Material
}

\author{
Siti Hadiyati Nur Hafida ${ }^{1}$, Mohd Hairy Ibrahim $^{2}$, Siti Azizah Susilawati ${ }^{3}$, Rahmat \\ Riandi Suparno ${ }^{4}$, Suharjo ${ }^{5}$, Wahyu Widiyatmoko ${ }^{6}$ \\ 1,2,3 Department of Geography and Environment, Universiti Pendidikan Sultan Idris, Malaysia \\ 4,5,6 Education Geography FKIP, Universitas Muhammadiyah Surakarta, Indonesia
}

DOI: 10.23917/ijolae.v2i1.9273

Received: November $18^{\text {th }}, 2019$. Revised: November $22^{\text {nd }}, 2019$. Accepted: November $23^{\text {th }}, 2019$ Available Online: November $25^{\text {th }}, 2019$. Published Regulary: January $1^{\text {st }}, 2020$.

\begin{abstract}
The purpose of this study is to improve student learning in geography subjects at class X of MA Muhammadiyah Gantung Belitung Timur in academic year 2018/2019 using the Jigsaw strategy. The subject of the study was class $\mathrm{X}$, amounting to 22 students. This research is a quasi-experimental research with pretestposttest design. This study uses a control and experimental group. The conclusion of this research is the implementation of Jigsaw strategy can improve the effectiveness of students in learning geography in class $\mathrm{X}$ of MA Muhammadiyah Gantung Belitung Timur. This is consistent with the results of the N-Gain Test in the experimental group which has an average of 31.97 and the control group has an average of 12.52 therefore, the experimental group has a medium value and the control group shows a low value. N-Gain test data showed that the experimental group learning was more effective than the control group. Learning outcomes between the experimental group and the control group showed a difference, the control group had an average pre-test value of 60 and an average post-test of 65. The experimental group had an average score of 61.82 and the post-test -test 74.09. The experimental group had higher pre-test and post-test scores compared to the control group, therefore Ha was accepted while Ho was rejected, this shows that the use of jigsaw learning strategies in the experimental group was effective in increasing students' knowledge and understanding of earth material as the space of life.
\end{abstract}

Keywords: jigsaw strategy, geography, effectiveness, learning process

Corresponding Author:

Siti Hadiyati Nur Hafida, Department of Geography and Environment, Universiti Pendidikan Sultan Idris, Malaysia

e-mail: hafida.siti5@gmail.com

\section{Introduction}

Increased understanding of a material have an obstacles, one of which is related to the learning methods used by teachers. Learning methods can improve learning outcomes in all beginning ability categories (Irawan, 2016; Widodo, 2015). When the learning process takes place in the classroom, there are some difficulties and problems that can make the learning process to be less effective which can affect to the student's learning outcomes. Zaduqisti (2014) states that the learning model is able to make students active in learning, so learning becomes more valuable, meaningful and can improve the learning competencies of students.

Successful education can be seen through student learning outcomes, which are generally indicated through grades. The quality and success of student learning are strongly influenced by the ability and accuracy of teachers in choosing and using the teaching methods. Teacher learning model begins to be abandoned by changing to be more modern because the teacher learning 
method make students less involved in learning activities. The student just sits, stay, listen, record and memorize all that teacher say. So these activities make students not participating in learning activities that tend to make them bored and lazy to learn (Isjoni, 2007).

The learning process is the process of developing knowledge through one's experiences and social interactions. These changes are usually relatively permanent and remain for a long time. Active learning is a function of interaction between the individual and situation which is determined by indicators as the development of basic competencies. Andriani (2013) reveals that one of the factors that caused less learning competency was the learning model such as, teachercentered. From this model, students does not have access to learn independently.

Cooperative learning is a learning model that prioritizes cooperation to achieve learning goals. Cooperative learning makes the students to be more active in the learning process, students must cooperate in their activities, and enhance the students selfesteem (Hoerunnisa \& Suherdi, 2017). Type of learning by divided students to be small group collaboratively, whose members consist of four to six people, with a heterogeneous group structure (Garcia, Abrego \& Robert, 2017; Majid, 2013). Adam (2013) states that cooperative learning is a methodology that uses various learning activities to enhance students' understanding of a subject using a structured approach that involves some steps that require students to create, analyze, and apply concepts. If the environment and input of students is good so the learning outcomes also be good and vice versa. If the environmental input and students are less so the learning outcomes also less or not good (Huang, 2008; Darmawan \& Suparman, 2019).

Jigsaw is a cooperative learning strategy that encourages each student to deepen a learning material through the 'home group' method (Hoerunnisa \& Suherdi, 2017; Azmin, 2016). Students compose groups with a certain number, each group representative will meet, they as 'expert groups' and after mastering a learning material, the representatives will explain it to their group members (Sabbah, 2016). Cooperative learning jigsaw strategy is cooperative learning in which students learn and they make small groups of 4-6 heterogeneous people and work together on positive interdependence and they are responsible for completing parts of the subject matter that must be learned and conveying the material to group members others (Ritonga, M; Ruslan, D; Alesyanti, 2017). Usually, jigsaw strategy set up with five students (Hoerunnisa \& Suherdi, 2017).

Isjoni (2009) states that Jigsaw is one type of cooperative learning that encourages learners more active and helps in mastering learning material to achieve the best results. According to Rusman (2013), Jigsaw strategy is also known as cooperative by experts because members of each group are faced with different problems, but the problems topic that faced by each group are the same, each messenger in a different group discusses the same material, we call it as experts team who has task in discussing the problems faced, then the results of the discussion are brought to the source group and delivered to members of the group. Each student is responsible for one subtopic and students will request another subtopic through an oral report from the participant. Therefore, students are responsible for reporting the same subtopic twice, once when they report to their group members, and second when discussing in an expert group (Yoshida, 2018).

Jhonson in Rusman (2013) conducted a study about Jigsaw cooperative learning which the result showed that cooperative interactions have various positive effects on children's development, there are improving learning outcomes, improving memory, achieve high levels of reasoning motivation, encourage motivation to grow intrinsic (individual awareness), enhance heterogeneous human relations, enhance positive children's attitudes toward school, increase children's self-esteem, enhance positive social adjustment behavior, and improve life in mutual cooperation.

Jigsaw strategy has been carried out in 
various sciences, such as language, social science and even medical science (Karacop, 2017). Although each science has different classroom practices according to developments in their respective fields, however, the implementation of a jigsaw strategy has greatly influenced the students' understanding in each sciences. Jigsaw strategy brings new changes in the health science curriculum, the jigsaw strategy allows each student to discuss with colleagues about some material in a short amount of time (Walkers, 2015). Jigsaw strategies can help students who have less capabilities to be assisted and mentored by students who have higher capabilities than him so, there is a positive interdependence, jigsaw also allows students to maintain the personal responsibility (Hoerunnisa \& Suherdi, 2017; Hamadneh, 2017; Sabbah, 2016). Futhermore, jigsaw strategy can increase the students motivation in learning, positive behavior, students achievement (Marhamah \& Mulyadi, 2013)

Jigsaw strategy can help students to actively participate in class activities and enhance an active atmosphere in learning (Mengduo \& Xiaoling, 2010). Despite the many benefits of implementing a jigsaw strategy in the learning process however, implementation of a jigsaw strategy would be more appropriate given to material related to the theory, not formulas (Sabbah, 2016). That is because, theory can be read by students themselves before learning in class begins so that students have basic knowledge before learning.

In a jigsaw strategy, the teacher organizes learning activities more communicatively, but this does not mean allowing students to learn on their own. The teacher must still help students in their learning by becoming actively involved. The teacher's main role is to choose learning materials, arrange groups, explain the nature of cooperative group work, provide a conducive environment for this type of work, monitor group work, and assist students in working with these materials (Mengduo \& Xiaoling, 2010).

The material that will be used in cooperative learning jigsaw is the material of the earth as the space of life, this material is divided into several indicators, that is understanding the theory of the formation of Earth, understanding the development of life on earth, understanding the impact of Earth's rotation and revolution on Earth's life, and understanding the dynamics of Earth as a space of life. Many learning materials related to the topic are suitable using jigsaw strategies. In addition, high school students are very easily bored during the learning process. High school students will prefer an active and dynamic learning process so that the absorption of learning material will be more effective and efficient.

Many types of learning strategies however, jigsaw strategies will divide students in the same group members with different backgrounds. Jigsaw strategy encourages teachers to pay attention to the schema or background of the students experience and help students to be more active so the learning material becomes more meaningful. Students work together with other students in an environment of mutual cooperation and have many opportunities to process information and improve communication skills (Slavin, 2008).

Based on the observations, most of the teachers at MA (Madrasah Aliyah/ Islamic Senior High School) of Muhammadiyah in Gantung, East Belitung still use the teachercentered method in the learning process. The result of the observation show that the students have less motivation in understanding the subject matter, that is caused by the learning strategies that used by the teachers that make students bored. According to the problems that discuss above, this study aims to find out the influence of jigsaw strategy on earth as life space material for students of class X MA Muhammadiyah Gantung in the academic year 2018/2019.

\section{Method}

This research is a quasi-experimental research that using pretest-posttest design. Experimental research can be defined as a systematic method for building relationships that contain causal-effect relationship 
(Sukardi, 2011). Furthermore, the experimental method is a research method used to look for the effect of certain treatments on others under controlled conditions (Sugiyono, 2011). The research began by giving pretest, treatments, and posttest to determine the impacts of jigsaw technique (Haerunnisa \& Suherdi, 2017) on earth's material as life space. This research involved two groups; experimental group and control group. The experimental group received treatment using a jigsaw strategy while the control group used a teacher-centered strategy.

Total students of class $\mathrm{X}$ in MA Muhammadiyah Gantung is 22 student, and divide into 2 class, that is XA and XB. So, this research used all students to do the quasi-experimental research. XA to be experimental group that used jigsaw strategy and $\mathrm{XB}$ is control group that used teachercentered strategy.

The data analysis using normality test, paired t-test, and $\mathrm{N}$-gain test. Normality test that using in this research is kolmogorovSmirnov test, this test is to know difference between pretest and posttest whether it normality distribution or not. The basis for decision making is if the value of Sig. or probability value $<0.05$, then the data are not normally distributed and if the Sig. or probability value $>0.05$ then the data is normally distributed.

Paired t-test is used to determine whether there is influence or not from abnormally distributed data in pairs (Pre test and Post test) and to find out the research hypothesis. The basis of decision making, if the probability is $<0.05$ then Ha (hypothesis alternative) is accepted, whereas if the probability is> 0.05 then Ho (hypothesis null) is accepted.

$\mathrm{N}$-gain test used to determine the effectiveness of jigsaw strategy using the Hake formula (Meltzer, 2002). The gain test formula in Hake (Meltzer, 2002; Archambault, 2008) is:

$$
\text { Gain }=\frac{\text { Skor Posttest }- \text { Skor Pretest }}{\text { Skor Ideal }- \text { Skor Pretest }}
$$

Table 1. The effectiveness category of $\mathrm{N}$-gain according to Hake

\begin{tabular}{cc}
\hline Percentage (\%) & Category \\
\hline $\mathrm{g}>70$ & High \\
$30<\mathrm{g} \leq 70$ & Medium \\
$\mathrm{g} \leq 30$ & Low \\
\hline
\end{tabular}

Source: Meltzer, 2002

\section{Result and Discussion}

The topic that discussed in this research is integrated geography with earth as life space. The jigsaw strategy was conducted in the experimental group by dividing 11 students into 4 groups and each group consisted of 3 to 2 students and each group is given one material indicator that they had to learn and understand. Group 1 must to learn about the theory of planetary formation, Groups 2 with material indicators that is the development of life on earth, Group 3 is the impact of earth's rotation and revolution on earth's life, and the last group learn about the dynamics of earth as living space. Members from different teams with the same topic meet for discussion (expert teams) and helping one another on the learning topics assigned to them. Then the learners return to the original team/ group to explain the other group members about what they have learned before at the expert team meeting.

In the Jigsaw cooperative learning model, there are origin and expert groups. The origin group is the main group of learners with diverse abilities, origins, and family backgrounds. The origin/source group is a combination of several experts. Expert groups are groups that consisting of members from different origin groups who are assigned to study and explore a particular topic, complete tasks related to the topic and must be explained to other members of origin group. The relationship between the 
original group and the expert group is described in figure 1.

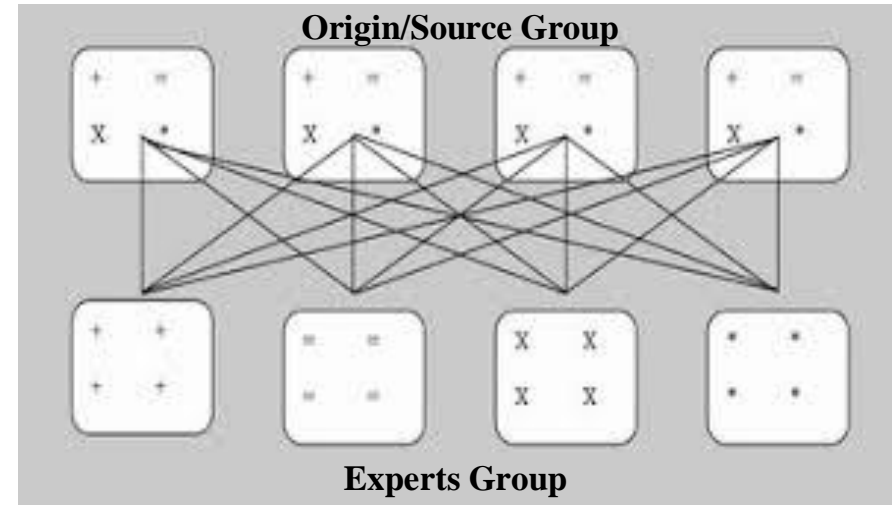

Figure 1. Jigsaw Group Ilustration

Source: Sahin, A. 2010

The study was conducted by giving pretest questions to students related to the themes. Pretest results are used to determine the initial abilities of students. After conducting the pretest, the researcher gave special treatment to the experimental class using a jigsaw strategy. Figure 2 is a documentation of the jigsaw strategy in XA.

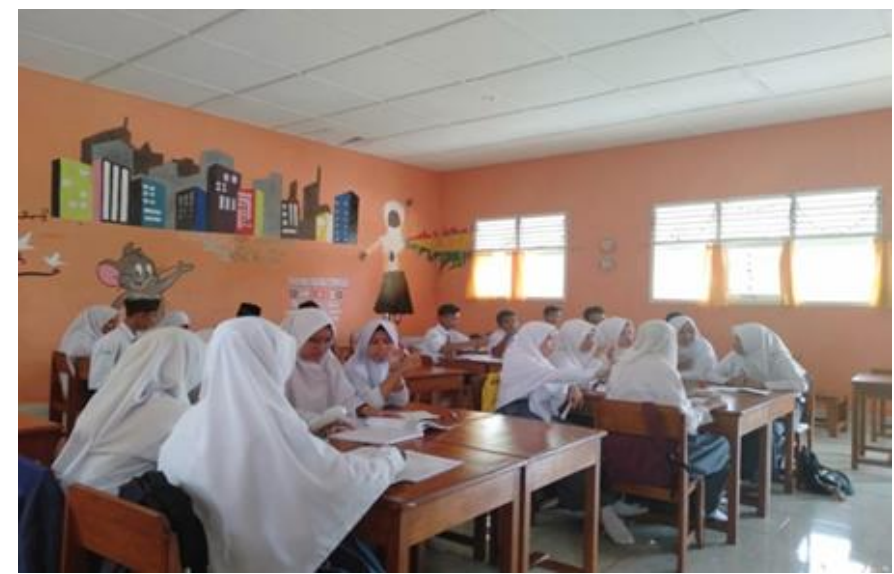

Figure 2. Implementation of jigsaw strategy

Data normality test is conducted using SPSS 16.0 software on the basic of taking decision, if the Sig. or probability value $<0.05$, then the data are not normally distributed and if the Sig. or probability value > 0.05 then the data is normally distributed.

\section{a. Normality Test of Control Group}

Figure 3 bellow shows that the pretest and posttest results in the control group have normally distributed data, because each pretest and posttest value is $>0.05$. Pretest has a value of sig. 0.621 and posttest 0.329 so, the data are normally distributed.

\begin{tabular}{|c|c|c|c|}
\hline \multicolumn{4}{|c|}{ One-Sample Kolmogorov-Smirnow Test } \\
\hline & & Pretest & Postest \\
\hline $\mathrm{N}$ & & 11 & 11 \\
\hline \multirow[t]{2}{*}{ Normal Parameters ${ }^{2}$} & Mean & 60.00 & 65.00 \\
\hline & Std. Deviation & 7.416 & 7.746 \\
\hline \multirow[t]{3}{*}{ Most Extreme Differences } & Absolute & .227 & .286 \\
\hline & Positive & .184 & .168 \\
\hline & Negative & -.227 & -.286 \\
\hline Kolmogorov-Smirnov Z & & .754 & .949 \\
\hline Asymp. Sig. (2-tailed) & & .621 & .329 \\
\hline
\end{tabular}

a. Test distribution is Normal.

Figure 3. Normality Data Test of Control Group 


\section{b. Normality Test of Experimental Group}

From figure 4 , can be seen that in experimental group also have normally distributed data. In pretest of experimental group have sig 0,653 and posttest is 0,843 , all sig value is $>0,05$ so, the data was normally distributed.

One-Sample Kolmogorov-Smirnov Test

\begin{tabular}{|ll|r|r|}
\hline & & Pretest & Postest \\
\hline N & & 11 & 11 \\
& Mermal Parameters & & \\
& Most Extreme Differences & 61.82 & 74.09 \\
& Std. Deviation & 8.448 & 7.355 \\
& Absolute & .222 & .186 \\
& Positive & .222 & .120 \\
Kolmogorow-Smirnov Z & Negative & -.197 & -.186 \\
Asymp. Sig. (2-tailed) & & .735 & .615 \\
\end{tabular}

a. Test distribution is Normal.

Figure 4. Normality Data Test of Expereimental Group

\section{c. Control - Experimental Group}

The N-Gain Test is used to determine the effectiveness of jigsaw strategy implementation. The $\mathrm{N}$-Gain Test measured difference scores between pre-test and posttest. N-Gain Test of the experimental group had an average of 31.97 and the control group had an average of 12.52. The N-Gain test calculation data shows that the experimental group had a medium value and the control group shows a low value. N-Gain test data showed that the experimental group learning was more effective than the control group.

$\mathrm{T}$ test (t-test) is calculated using the paired samples of $\mathrm{T}$ test method. The result of $\mathrm{T}$ test analysis on the pre-test and post-test values are accepted if the value of $\mathrm{HO}>0.05$ and $\mathrm{H} 0$ will reject if the significant value $<0.05$. The following results of the $\mathrm{T}$ test in this study:

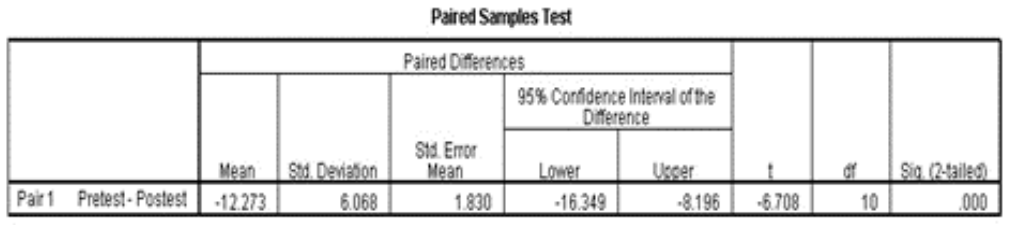

Figure 5. T test of Experimental Group

Based on figure 5, the experimental class had a sig (2- tailed) value of 0,000 or $<0.05$. This means that $\mathrm{Ha}$ is accepted while Ho is rejected, showing that the implementation of jigsaw learning strategies in the experimental group is effective. From jigsaw strategy, students can develop their own learning material than the students that used teacher-centered strategy. Students can help each other to improve better understanding of an aspects, other than that, students learn the importance of finding additional information related to their own learning material. If students do not search the additional information, students will difficult to understand the learning material.
The following results are the average pre-test and post-test scores of the control group and the experimental group.

Figure 6 bellow shows that the control group and the experimental group both experienced an increase in learning outcomes. The control group had an average pre-test value of 60 and an average post-test of 65 , resulting in an average increase of 5 in the control class. The experimental group had an average pre-test value of 61.82 and an average post-test of 74.09 so, there was an increase of 12.27 in the experimental group. The experimental group had higher pre-test and post-test scores than the control class. 


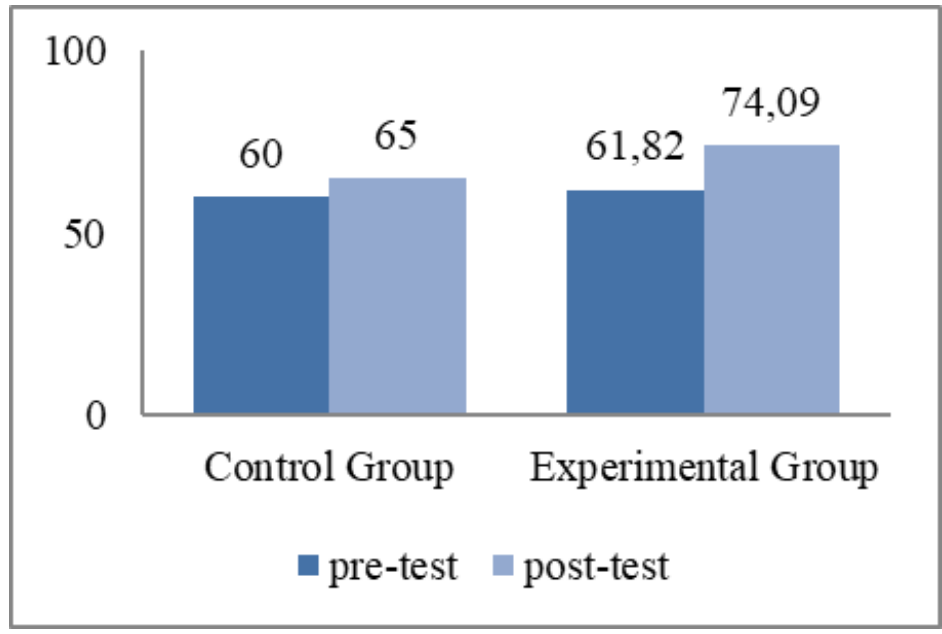

Figure 6. Pre-test and post-test score of the control group and experimental group

Comparison between pretest and posttest in the control and experiment group shows that the experimental group has increased values higher than the control class. Thus, the use of a jigsaw strategy effectively increases students' knowledge and understanding in the material of the earth as a space of life.

\section{Conclusion}

The jigsaw strategy is more effective in achieving learning objectives on earth material as a living space compared to the teacher-center strategy. This is proven by using a jigsaw strategy so that students in the experimental group can increase the average score to reach 74.09, an increase of 12.27 compared to the pretest score. The N-Gain Test Test in the experimental group had an average of 31.97 and the control group had an average of 12.52. The N-Gain test calculation data showed that the experimental group has a medium value and the control group shows a low value. N-Gain test data showed that the experimental group learning was more effective than the control group.

\section{References}

Adams, F. H. (2013). Using Jigsaw Technique as an Effective Way of Promoting Cooperative Learning
Among Primary Six Pupils in Fijai. International Journal of Education and Practice, 1(6), 64-74. Retrieved from http://www.pakinsight.com/journals/IJ EP.htm.

Andriani, D. G., K, T. A., \& Mardiyana. (2013). Eksperimentasi Model Pembelajaran Kooperatif Tipe Jigsaw II dan Think Pair Share Ditinjau dari Kecerdasan Emosional Siswa SMP SeKota Kediri Tahun Pelajaran 2012/ 2013. Jurnal Elektronik Pembelajaran Matematika, 1(7), 651-660.

Arikunto, Suharsimi. (2006). Prosedur Penelitian. Jakarta: PT Rineka Cipta.

Azmin, N. H. (2016). Effect of the JigsawBased Cooperative Learning Method on Student Performance in the General Certificate of Education AdvancedLevel Psychology: An Exploratory Brunei Case Study. International Education Studies, 9(1), 91. https://doi.org/10.5539/ies.v9n1p91.

Darmawan, E. W., \& Suparman, S. (2019). Design of Mathematics Learning Media based on Discovery Learning to Improve Problem Solving Ability. IJOLAE Indonesian Journal on Learning and Advanced Education, 1(2),20-28. 
https://doi.org/10.23917/ijolae.v1i2.75 64

Garcia, B. A., Ed, D., Abrego, J., Ed, D., \& Robert, R. (2017). Using the Jigsaw Method for Meaningful Learning to Enhance Learning and Rentention in an Educational Leadership Graduate School Course. Global Journal of $\mathrm{Hu}$ man-Social Science: G Linguistics and Education, 17(5).

Hamadneh, Q. M. S. (2017). The Effect of Using Jigsaw Strategy in Teaching Science on the Acquisition of Scientific Concepts among the Fourth Graders of Bani Kinana Directorate of Education. Journal of Education and Practice, 8(5), 127-134.

Huang, Y. M., Huang, T. C., \& Hsieh, M. Y. (2008). Using annotation services in a ubiquitous Jigsaw cooperative learning environment. Educational Technology and Society, 11(2), 3-15.

Hoerunnisa, Neneng; Suherdi, D. (2017). The Effectiveness of Jigsaw in Improving Students' Reading Comprehension. Journal of English and Education, $\quad 5(1)$, 1-12. https://doi.org/10.2991/seadric17.2017. 50

Irawan, V.T. (2016). Pengaruh Blanded Learning dan Kemampuan Awal Siswa Terhadap Hasil Belajar Mata Pelajaran Pemeliharan Kelistrikan Kendaraan Ringan di Kelas IX TKR SMK Negeri 3 Singaraja. Thesis. Unpublished. Malang: PPs TM UM.

Karacop, A. (2017). The Effects of Using Jigsaw Method Based on Cooperative Learning Model in the Undergraduate Science Laboratory Practices. Universal Journal of Educational Research, 5(3), 420-434. https://doi.org/10.13189/ujer.2017.050 $\underline{314}$
Majid, Abdul. (2013). "Strategi pembelajaran". Bandung: Remaja Roskarya offset.

Marhamah, M., \& Mulyadi, M. (2013). Jigsaw Cooperative Learning: A Viable Teaching-Learning Strategy? Journal of Educational and Social Research, 3(7), 710-715. https://doi.org/10.5901/jesr.2013.v3n7 p710

Meltzer, D. E. (2002). The relationship between mathematics preparation and conceptual learning gains in physics: A possible "hidden variable" in diagnostic pretest scores. American Journal of Physics, 70(12), 1259-1268. https://doi.org/10.1119/1.1514215

Mengduo, Q., \& Xiaoling, J. (2010). Jigsaw Strategy as a cooperative learning technique: focusing on the language learners. Chinese Journal of Applied Linguistics (Foreign Language Teaching \& Research Press), 33(4), 113125.

Ritonga, M., \& Ruslan, D. (2017). The Effect of Jigsaw Learning Strategy to Students, Civic Learning Outcomes in Grade V SDN 107403 Cinta Rakyat Academic Year 2016 / 2017. IOSR Journal Of Research \& Method in Education (IOSR-JRME), 7(5), 64-72. https://doi.org/10.9790/73880705056472

Sabbah, S. S. (2016). The Effect of Jigsaw Strategy on ESL Students' Reading Achievement. Arab World English Journal, 7(1), 445-458.

Sahin, A. (2010). Effects of Jigsaw III technique on achievement in written expression. Asia Pacific Education Review, 12(3), 427-435.

Sanjaya, Wina. (2010). Strategi Pembelajaran Berorientasi standar Proses 
Pendidikan. Jakarta: Prenada Media Group.

Slavin, R. E. (2005). Cooperative Learning. Jakarta: Nusa Media.

Slavin, R. E. (2011). Psikologi Pendidikan Teori Dan Praktik. Jakarta: PT Indeks.

Sugiyono. (2012). Metode Penelitian Pendidikan Pendekatan Kuantitatif, Kualitatif, dan $R \& D . \quad$ Bandung: Alfabeta CV.

Sukardi. 2011. Metodologi Penelitian Pendidikan Kompetensi dan Praktiknya. Yogyakarta: Bumi Aksara.

Sukmadinana, Nana Syaodih. 2013. Metode Penelitian Pendidikan. Bandung : PT Remaja Rosdakarya.

Walker, S., Olvet, D. M., \& Chandran, L. (2015). The jigsaw technique of peer teaching and learning: An efficient and enjoyable teaching strategy in medicine. MedEdPublish, 6(14). https://doi.org/10.15694/mep.2015.006 .0014

Widodo, Sujadi, I., \& Riyadi. (2015). Eksperimentasi Model Pembelajaran
Kooperatif Tipe Jigsaw dengan Guided Discovery Learning pada Materi Bangun Ruang Sisi Datar Ditinjau dari Locus of Control. Jurnal Elektronik Pembelajaran Matematika, 3(3), 268280.

Yoshida, M. (2018). Communication Jigsaw: A teaching method that promotes scholarly communication. International Journal of Emerging Technologies in Learning, 13(10), 208-224. https://doi.org/10.3991/ijet.v13i10.885 0

Zaduqisti, E. (2010). Problem-based Learning (Konsep Ideal Model Pembelajaran untuk Peningkatan Prestasi Belajar dan Motivasi Berprestasi). Forum Tarbiyah, 8(2), 181-191. https://doi.org/10.4049/jimmunol.168.1 2.6189 